\title{
D-OPTIMAL DESIGN OF EXPERIMENTS AND COMPREHENSIVE RHEOLOGI- CAL ANALYSIS IN THE DEVELOPMENT OF NATURAL ANTI-AGING CREAMS
}

Sanela M. Savić ${ }^{1}$ Nebojša D. Cekić ${ }^{1},{ }^{2}$ Saša R. Savić ${ }^{*}$

${ }^{1}$ DCP Hemigal, Leskovac, Serbia

2 Faculty of Technology, University of Niš, Leskovac, Serbia

This work is focused on the development and evaluation of completely natural anti-aging creams, with the aid of the experimental design. Model formulations, differing in the content of emollients $(10 \% / 15 \% / 20 \%)$ and emulsifier $(1 \% / 2 \% / 3 \%)$ and containing the Acmella oleracea extract as a model anti-aging active were prepared by the cold process and evaluated regarding rheological behavior (continuous rotational and oscillatory tests) and physical stability (dynamic-mechanical thermoanalysis-DMTA test). To study the influence of varied formulation parameters and their interaction on the critical rheological characteristics of the developed creams, a D-optimal design within the response surface method was applied. The data acquired from rheological characterization revealed favorized pseudoplastic (shear-thinning) flow behavior with the yield point, and dominating elastic behavior (storage modulus G' > loss modulus G") in both, amplitude and frequency sweeps, which together with a rather small and constant structural change obtained in the DMTA test indicated satisfying overall physical stability of formulated creams. The results of D-optimal design showed a significant individual, as well as a mutual effect of the tested formulation factors (emollient concentration, emulsifier concentration) affecting critical quality attributes (apparent viscosity, yield point, flow point, G', G", structural change) of developed anti-aging creams. Based on optimization results, the model formulation containing $20 \%$ of the emollient mixture and $2 \%$ of the emulsifier was selected as preferred in terms of required rheological properties and, thus, desired stability and quality, and it could be considered as a promising candidate worth exploring further for efficacy and in vivo skin performances.
(ORIGINAL SCIENTIFIC PAPER)

UDC 665.58:66.06

DOI: $10.5937 /$ savteh2002029S

Keywords: natural cosmetics, experimental design, rheological parameters, continuous rotational test, oscillatory test, DMTA method

\section{Introduction}

Nowadays, in what has been called a 'clean beauty era', the growing consumers' awareness of environmental conservation and protection and the sustainable development, on the one hand, and the needs and wants for appearing youthful and healthy, at any age, on the other hand, have triggered an increasing trend of natural anti-aging products. First of all, these products are expected by consumers to be safe, high-quality, high-performance with immediate as well as long-term perceivable benefits [1-4]. However, formulating with natural ingredients is a quite challenging task due to often diminished efficacy compared to their synthetic counterparts, a difficulty to control rheology of the final product, limited or compromised product aesthetics and stability, as well as the increased cost [4]. Overcoming these challenges, without compromising the product performance, is the key to the successful development of cosmetic products based exclusively on natural ingredients.

Furthermore, during the formulation development, in order to get the high-quality cosmetic product that safely provides the desired effects/benefits to consumers, multiple factors, formulation as well as processing should be taken into consideration, as these factors may have different and significant influence on the critical properties and stability and, consequently, on the efficacy and overall acceptability of developed formulations. In this context, a scientific and systematic design of experiments (DoE) approach has been recognized as a valuable tool for the development, improvement and optimization of cosmetics formulation and preparation [5-7]. By implementing the experimental design strategy, one would be able to identify and manage the critical quality attributes of developed products, to establish, predict and control the way these attributes are influenced by different formulation and process variables and their interactions and, thus, to ensure the desired/optimized product performances $[8,9]$.

With this in mind, the aim of the present work was to develop the anti-aging creams based entirely on natural ingredients and to assess the way critical rheological properties of formulated creams are affected by variations of the formulation composition by employing computer-generated D-optimal experimental design, with the ultimate goal being the selection of candidate(s) with a desired rheological profile. For

\footnotetext{
*Author address: Saša Savić, Faculty of Technology, University of Niš, Bulevar oslobođenja 124, 16000 Leskovac, Serbia

E-mail: sasa.savic@tf.ni.ac.rs

The manuscript received: November, 11, 2020.

Paper accepted: December, 04, 2020.
} 
this purpose, a series of cosmetic creams stabilized with the novel natural glycolipid emulsifier and containing Acmella oleracea (L.) R. K. Jansen extract as a model active substance were prepared by the cold process and thoroughly characterized by isothermal continuous rotational and oscillatory rheological measurements. The employed D-optimal design has enabled: (1) to analyze simultaneously the effects of key formulation components (emollient and emulsifier concentration) on the critical quality attributes of developed creams (viscosity, yield point, flow point, storage and loss moduli, loss factor, structural change); (2) to discover and estimate significant interactions between tested variables, and (3) to optimize the formulation of natural anti-aging cream in order to provide desired rheological performance and stability. In order to cut down the time needed for physical stability evaluation of developed creams, an original, previously developed and fully described dynamic-mechanical thermoanalysis (DMTA) test was applied as a rapid rheological simulation of accelerated freeze-thaw stability testing $[10,11]$.

\section{Experimental}

\section{Materials}

The raw materials used for the preparation of model natural anti-aging creams, with INCI (International Nomenclature of Cosmetic Ingredients) names and designated manufacturers/suppliers are listed in Table 1. All chemicals were of cosmetic or pharmaceutical grade and were used without further purification.

\section{Preparation of natural anti-aging creams}

Natural anti-aging creams (Table 1), differing in the concentration of used emollients and the emulsifier (according to the applied experimental design, Table 2), were prepared by the cold emulsification process, at ambient temperature $\left(22 \pm 1^{\circ} \mathrm{C}\right)$. Briefly, the glycolipid O/W emulsifier was added to the water and stirred $(4,000 \mathrm{rpm}, 20 \mathrm{~s})$ with a rotor-stator homogenizer (IKA Ultra-Turrax ${ }^{\circledR}$ T25 digital, IKA ${ }^{\circledR}$-Werke $\mathrm{GmbH} \& \mathrm{Co}$. KG, Germany), after which the glycerin was added and homogenously mixed in. The separately prepared oil phase consisting of the mixture of emollients (phase A) was then added to the water phase (phase B) under stirring $(4,400 \mathrm{rpm})$, and further homogenized with the rotor-stator homogenizer at 6,000 rpm for $4 \mathrm{~min}$. Afterwards, a rheological modifier (phase $\mathrm{C}$ ) was added to the emulsion and homogenously mixed with an overhead stirrer (IKA Eurostar 60 VR Control, IKA -Werke GmbH \& Co. KG), equipped with the propeller mixing tool, at $800 \mathrm{rpm}$ for 10 min. Finally, the components of phase $D$ were sequentially added and mixed by overhead stirrer ( $800 \mathrm{rpm}, 5 \mathrm{~min}$ ), upon which the homogenous emulsion was obtained. The $\mathrm{pH}$ value of the resulting emulsion was adjusted to 5.5-6.0 using $\mathrm{NaOH}$ (30\% aqueous solution). Such obtained final emulsion samples were packed in glass jars with screw caps, and after $48 \mathrm{~h}$ of storage at $22 \pm 1^{\circ} \mathrm{C}$, their rheological characterization was performed.

Table 1. Composition of the developed natural anti-aging creams

\begin{tabular}{|c|c|c|c|c|}
\hline Raw material & Ingredient INCI name & $\begin{array}{c}\text { Manufacturerl } \\
\text { Supplier }\end{array}$ & $\begin{array}{c}\text { Concentration in the } \\
\text { model formulation } \\
(\%, w / w)\end{array}$ & Function \\
\hline $\begin{array}{l}\text { A. } \\
\text { Cegesoft }{ }^{\circledR} \text { PS } 6 \\
\text { Myritol }^{\circledR} 318\end{array}$ & $\begin{array}{l}\text { Vegetable Oil } \\
\text { Caprylic/Capric Triglyceride }\end{array}$ & $\begin{array}{l}\text { BASF, Germany } \\
\text { BASF, Germany }\end{array}$ & & \\
\hline Tegosoft $^{\circledR} \mathrm{XC}$ & Phenoxyethyl Caprylate & $\begin{array}{l}\text { Evonik Operations } \\
\text { GmbH, Germany }\end{array}$ & $10.0 / 15.0 / 20.0^{*}$ & $\begin{array}{l}\text { Emollient; } \\
\text { Oil phase } \\
\text { component }\end{array}$ \\
\hline $\begin{array}{l}\text { Emogreen }^{T M} L 15 \\
\text { Emogreen }^{T M} L 19 \\
\text { B. }\end{array}$ & $\begin{array}{l}\text { C15-19 Alkane } \\
\text { C15-19 Alkane }\end{array}$ & $\begin{array}{l}\text { SEPPIC, France } \\
\text { SEPPIC, France }\end{array}$ & & \\
\hline Fluidifeel $^{\mathrm{TM}}$ Easy & $\begin{array}{l}\text { Lauryl Glucoside (and) } \\
\text { Myristyl Glucoside (and) } \\
\text { Polyglyceryl-6 Laurate }\end{array}$ & SEPPIC, France & $1.0 / 2.0 / 3.0^{\star}$ & Emulsifier \\
\hline Purified water & Aqua & $\begin{array}{l}\text { DCP Hemigal, } \\
\text { Serbia }\end{array}$ & ad 100.0 & $\begin{array}{c}\text { Solvent; } \\
\text { Water phase } \\
\text { component }\end{array}$ \\
\hline $\begin{array}{l}\text { Glycerine } 99,5 \\
\text { Pharma }\end{array}$ & Glycerin & $\begin{array}{l}\text { Saveo GmbH, } \\
\text { Germany }\end{array}$ & 3.0 & $\begin{array}{l}\text { Humectant; } \\
\text { Water phase } \\
\text { component }\end{array}$ \\
\hline $\begin{array}{l}\text { C. } \\
\text { Solagum }{ }^{\mathrm{TM}} \mathrm{AX} \\
\text { D. }\end{array}$ & $\begin{array}{l}\text { Acacia Senegal Gum (and) } \\
\text { Xanthan Gum }\end{array}$ & SEPPIC, France & 1.2 & $\begin{array}{l}\text { Viscosity modifier } \\
\text { (thickener) }\end{array}$ \\
\hline Nipaguard $^{\circledR}$ SCE & $\begin{array}{l}\text { Sorbitan Caprylate (and) } \\
\text { Propanediol (and) Benzoic } \\
\text { Acid }\end{array}$ & $\begin{array}{l}\text { Clariant } \\
\text { International Ltd., } \\
\text { Switzerland }\end{array}$ & 1.0 & Preservative \\
\hline $\begin{array}{l}\text { Gatuline }^{\circledR} \\
\text { Expression AF }\end{array}$ & $\begin{array}{l}\text { Polypropanediol-4 (and) } \\
\text { Water (and) Acmella } \\
\text { Oleracea Extract }\end{array}$ & Gattefossé, France & 2.0 & Anti-aging active \\
\hline
\end{tabular}

Rheological characterization

The rheological behavior of the developed anti-aging creams was assessed using a MCR 302 air-bearing rheometer (Anton Paar, Austria), equipped with the parallel plate system (PP50/S as sandblasted measuring tool, sandblasted lower plate, lower Peltier element P- 
PTD 200, upper Peltier element H-PTD 200 including the evaporation blocker system; gap of $1 \mathrm{~mm}$ between plates) and controlled by RheoCompass ${ }^{\mathrm{TM}}$ software (Anton Paar). All measurements were performed in triplicate.

Viscosity curves and flow curves (continuous rotational tests) were obtained using shear rate range of $0.01-10 \mathrm{~s}^{-1}$, at $20^{\circ} \mathrm{C}$. RheoCompas ${ }^{\mathrm{TM}}$ software was programed to interpolate the values of apparent viscosity at shear rate of $5 \mathrm{~s}^{-1}$. Dynamical-mechanical analysis (oscillatory tests) included amplitude and frequency sweeps, conducted in that particular order for each investigated sample. Amplitude sweeps were performed first in order to get the value of limiting deformation $\left(Y_{L}\right)$ required to carry out subsequent frequency sweeps and DMTA test, without the irreversible structural change [12]. Amplitude sweeps were carried out using radial frequency value ( $\omega)$ of $10 \mathrm{rad} / \mathrm{s}$, in the deformation range of $0.01-100 \%$. Except deformation limit $\left(V_{L}\right)$, parameters acquired from this test were: storage modulus (G'), loss modulus (G"), yield point (yield stress), flow point, and loss factor (tanס $\left.=G^{\prime \prime} / G^{\prime}\right)$. Frequency sweeps were conducted at deformation $Y_{L}$ (generated from initial amplitude sweeps) or lower, that is, in the range of reversible elastic deformations (linear viscoelastic, LVE region), while $\omega$ value was in the range of $0.01-100 \mathrm{rad} / \mathrm{s}$.

\section{Stability study}

DMTA test, recently developed as the rheological simulation of the routine freeze-thaw test in the stability chamber [10,11], was also conducted in the LVE region, at deformation values equal to or lower from the $V_{L}$ value for respective model formulations, while $\omega$ was set at $10 \mathrm{rad} / \mathrm{s}$. Briefly, the test was designed to monitor, at thermal equilibrium $\left(20^{\circ} \mathrm{C}\right)$, the change of $\mathrm{G}^{\prime}{ }_{\max }$ value of each subsequent cycle of temperature oscillation $\left(G_{\max , n}^{\prime}, n=1-6\right)$ in relation to the $G_{\text {max }}^{\prime}$ value of the initial measurement (before temperature oscillation, $\mathrm{G}_{\max , \mathrm{t})}$ ), thus allowing the calculation of Delta $(\Delta)$ value, as a measure of structural change of the investigated sample $\left(\Delta=G_{\text {max }, n}^{\prime} / G_{\text {max,t0 }}^{\prime}, n=1-6\right)$ [13], after which Delta difference, as an absolute value, was calculated $\left(\Delta_{\text {difference }}=\left|\Delta_{\mathrm{n}}-\Delta_{\mathrm{t} 0}\right|, \mathrm{n}=1-6\right)$. Temperature oscillations $\left(20^{\circ} \mathrm{C}\right.$ to $45^{\circ} \mathrm{C} / 45^{\circ} \mathrm{C}$ to $-5^{\circ} \mathrm{C} /-5^{\circ} \mathrm{C}$ to $20^{\circ} \mathrm{C}$ ) were programed only once and repeated using internal loop in the RheoCompass ${ }^{\mathrm{TM}}$ software $[10,11]$. The rate of the temperature change was $5{ }^{\circ} \mathrm{C} / \mathrm{min}$. The sample structure recovery time was set to be 2 min.

\section{RSM Optimal experimental design}

During the development of a natural anti-aging cream, a computer-generated experimental design within the response surface method (RSM) was applied to evaluate the simultaneous influence of multiple formulation variables on critical quality attributes of the developed model creams. The concentration of emollient and the concentration of emulsifier were established to be the main formulation factors that can significantly affect the physicochemical properties, especially rheological per- formances and the stability of emulsions. Considering these findings and additional multilinear constraints in a defined experimental space, an optimal RSM design (D-criterion) was chosen to systematically analyze both, the direct effect of each individual variable (emollient and emulsifier concentration) as well as their interaction effects, in order to find the optimal conditions leading to creams with desired rheological features.

According to the applied D-optimal design, eight experimental runs were generated and randomly performed, with two replicates per batch. The factor settings, the experimental design matrix, and the responses of each experiment are shown in Table 2. As the response variables, the apparent viscosity, G', G", yield point, flow point, loss factor, and Delta difference value of the designed anti-aging creams were determined. Using the response surface regression procedure, the experimentally obtained data were analyzed to fit an adequate polynomial model which could best predict the investigated response within the constrained region of interest. The general form of the quadratic model, a second-order polynomial, assumed to fit the experimental results (for D-optimal purposes) [8,14], is presented in the following equation [Eq. (1)]:

$Y=\beta_{0}+\beta_{1} A+\beta_{2} B+\beta_{12} A B+\beta_{11} A^{2}+\beta_{22} B^{2} \cdots \ldots \ldots \ldots$. [Eq.

where $Y$ is the observed response or a dependent variable; $A$ and $B$ are the factors or independent variables; $\beta_{0}$ is the intercept; $\beta_{1}$ and $\beta_{2}$ are the linear coefficients of the respective independent variables $(A, B) ; \beta_{12}$ is the interaction coefficient associated with respective model factors' interaction (AB); and $\beta_{11}$ and $\beta_{22}$ are the quadratic coefficients of the independent variables $\left(A^{2}, B^{2}\right)$.

\section{Statistical analysis}

For building design, data processing and statistical analysis (analysis of variance, ANOVA), the Design-Expert $^{\circledR}$ software (version 11.1.0; Stat-Ease Inc., Minnesota, USA) was employed. The best predictive models for the investigated responses were proposed based on the significant model terms (factors and factors' interaction coefficients, $p<0.05$ ), maximized values for the multiple correlation coefficient ( $R$-squared, $R^{2}$ ) and adjusted $R^{2}$, as well as the reasonable agreement of the predicted $R^{2}$ with the adjusted $R^{2}$ (the difference less than 0.2 ), all provided by Design-Expert ${ }^{\circledR}$. To find the optimum levels for the tested factors yielding the desired rheological performances of the developed model anti-aging creams, the numerical and graphical optimization procedures were performed. For easier interpretation of the factors' interaction and better understanding of how the effect of one factor was influenced by the change in the level of the other one, interaction plots, contour plots, and threedimensional (3D) surface plots of the evaluated responses were also constructed. 


\section{Results and discussion}

RSM Optimal experimental design - Factor analysis In the course of the formulation development of natural anti-aging cream comprising a mixture of emollients with different polarities, stabilized by novel glycolipid emulsifier, and containing $A$. oleracea extract as a model active, the simultaneous influence of key formulation factors, namely the concentration of emollients and emulsifier, on the critical quality attributes of the developed model creams was evaluated by employing the computer-generated Doptimal experimental design with two factors at three levels each (emollient concentration: 10, 15 and 20\%; emulsifier concentration: 1, 2 and $3 \%$ ). The purpose was to gain better perception of how rheological properties of the developed natural creams are affected by variations of their compositions, that enabled to account significant interactions between independent variables tested, which are not possible to detect with the traditional one-factorat-a-time method. Concordant with constructed optimal RSM design matrix (Table 2), a total of eight different emulsion formulations were prepared using cold emulsification process and thoroughly characterized regarding their rheological behavior by performing the continuous rotational test, the oscillatory tests (amplitude and frequency sweeps), and DMTA test. Here, it is important to note that the model anti-aging cream formulated with high level of emollients (20\%) could not be stabilized with the low level of emulsifier (1\%) and this candidate point was set as a constraint in a process design.

Table 2. RSM D-optimal experimental design matrix with the response values of the developed anti-aging creams

\begin{tabular}{|c|c|c|c|c|c|c|c|c|c|}
\hline \multicolumn{2}{|c|}{ Formulation code } & Fs $1 / 10$ & Fs $1 / 15$ & Fs $2 / 10$ & Fs $2 / 15$ & Fs $2 / 20$ & Fs $3 / 10$ & Fs $3 / 15$ & Fs $3 / 20$ \\
\hline \multirow{2}{*}{$\begin{array}{l}\text { Factor A: } \\
\text { Emollient } \\
\text { concentration }\end{array}$} & Coded & -1 & 0 & -1 & 0 & +1 & -1 & 0 & +1 \\
\hline & Actual (\%) & 10 & 15 & 10 & 15 & 20 & 10 & 15 & 20 \\
\hline \multirow{5}{*}{$\begin{array}{l}\text { Factor B: } \\
\text { Emulsifier } \\
\text { concentration }\end{array}$} & Coded & -1 & -1 & 0 & 0 & 0 & +1 & +1 & +1 \\
\hline & Actual (\%) & 1 & 1 & 2 & 2 & 2 & 3 & 3 & 3 \\
\hline & $\begin{array}{l}\text { Apparent viscosity } \\
\text { (mPa.s) }\end{array}$ & $\begin{array}{c}15404 \\
\pm 61\end{array}$ & $\begin{array}{c}15628 \\
\pm 59\end{array}$ & $\begin{array}{c}14903 \\
\pm 40\end{array}$ & $\begin{array}{c}14573 \\
\pm 49\end{array}$ & $\begin{array}{c}15448 \\
\pm 64\end{array}$ & $\begin{array}{c}13814 \\
\pm 35\end{array}$ & $\begin{array}{l}14136 \\
\pm 6\end{array}$ & $\begin{array}{c}13860 \\
\pm 16\end{array}$ \\
\hline & $\mathrm{G}^{\prime}(\mathrm{Pa})$ & $\begin{array}{l}208 \\
\pm 0\end{array}$ & $\begin{array}{l}222 \\
\pm 0\end{array}$ & $\begin{array}{l}211.5 \\
\pm 0.71\end{array}$ & $\begin{array}{l}227 \\
\pm 0\end{array}$ & $\begin{array}{l}243.5 \\
\pm 0.71\end{array}$ & $\begin{array}{c}205 \\
\pm 1.41\end{array}$ & $\begin{array}{l}216.5 \\
\pm 3.54\end{array}$ & $\begin{array}{l}223.5 \\
\pm 0.71\end{array}$ \\
\hline & $\mathrm{G}^{\prime \prime}(\mathrm{Pa})$ & $\begin{array}{l}26.94 \\
\pm 0.15\end{array}$ & $\begin{array}{l}26.75 \\
\pm 0.16\end{array}$ & $\begin{array}{l}25.8 \\
\pm 0.09\end{array}$ & $\begin{array}{l}25.76 \\
\pm 0.48\end{array}$ & $\begin{array}{l}25.57 \\
\pm 0.07\end{array}$ & $\begin{array}{l}24.91 \\
\pm 0.03\end{array}$ & $\begin{array}{l}24.36 \\
\pm 0.86\end{array}$ & $\begin{array}{l}23.69 \\
\pm 0.39\end{array}$ \\
\hline \multirow[t]{4}{*}{$\begin{array}{l}\text { Response } \\
(\text { mean } \pm \text { SD) }\end{array}$} & Yield point $(\mathrm{Pa})$ & $\begin{array}{r}6.90 \\
\pm 0.65\end{array}$ & $\begin{array}{c}8.21 \\
\pm 0.35\end{array}$ & $\begin{array}{r}6.90 \\
\pm 0.35\end{array}$ & $\begin{array}{c}7.34 \\
\pm 0.68\end{array}$ & $\begin{array}{c}9.52 \\
\pm 0.46\end{array}$ & $\begin{array}{l}6.61 \\
\pm 0.95\end{array}$ & $\begin{array}{r}7.10 \\
\pm 0.17\end{array}$ & $\begin{array}{c}8.24 \\
\pm 0.61\end{array}$ \\
\hline & Flow point $(\mathrm{Pa})$ & $\begin{array}{r}79.82 \\
\pm 0.23\end{array}$ & $\begin{array}{l}80.59 \\
\pm 0.18\end{array}$ & $\begin{array}{l}76.86 \\
\pm 0.24\end{array}$ & $\begin{array}{r}74.06 \\
\pm 0.37\end{array}$ & $\begin{array}{l}78.67 \\
\pm 0.1\end{array}$ & $\begin{array}{l}71.14 \\
\pm 0.21\end{array}$ & $\begin{array}{l}71.22 \\
\pm 0.88\end{array}$ & $\begin{array}{l}70.10 \\
\pm 0.01\end{array}$ \\
\hline & Loss factor & $\begin{array}{r}0.130 \\
\pm 0.001\end{array}$ & $\begin{array}{c}0.121 \\
\pm 0.001\end{array}$ & $\begin{array}{c}0.122 \\
\pm 0\end{array}$ & $\begin{array}{c}0.114 \\
\pm 0.002\end{array}$ & $\begin{array}{l}0.105 \\
\pm 0\end{array}$ & $\begin{array}{c}0.122 \\
\pm 0.001\end{array}$ & $\begin{array}{c}0.113 \\
\pm 0.002\end{array}$ & $\begin{array}{r}0.106 \\
\pm 0.001\end{array}$ \\
\hline & $\begin{array}{l}\text { Delta difference } \\
(\%)\end{array}$ & $\begin{array}{c}2.13 \\
\pm 0.03\end{array}$ & $\begin{array}{c}0.83 \\
\pm 0.91\end{array}$ & $\begin{array}{c}1.51 \\
\pm 0.42\end{array}$ & $\begin{array}{l}1.33 \\
\pm 0\end{array}$ & $\begin{array}{c}0.44 \\
\pm 0.61\end{array}$ & $\begin{array}{c}0.74 \\
\pm 0.33\end{array}$ & $\begin{array}{c}0.60 \\
\pm 0.49\end{array}$ & $\begin{array}{c}0.55 \\
\pm 0.09\end{array}$ \\
\hline
\end{tabular}

The data acquired from rheological characterization of all formulated anti-aging creams that were part of Doptimal design are presented in Table 2 and visualized in Figures 1-5. For each measured response, the effects corresponding to the investigated factors (emollient concentration, emulsifier concentration) and interactions were calculated and their statistical significance was checked. Factors and interactions with $p<0.05$ were considered significant. The terms with the insignificant influence on the estimated responses $(p>0.1)$ were excluded, except those required to maintain hierarchy (family structure) [14], and by these means the reduced models for estimated rheological parameters were generated. The resulting final response equations in terms of coded factors, coefficient estimation and statistical assessment of the selected models are given in Table 3, while the graphical representations of the fitted models are depicted in Figures 1-5, in the form of contour and 3D surface plots.

The ANOVA statistics showed the generated models for all investigated rheological parameters to be significant, as evidenced by model F values ( $p<0.05$; Table 3 ), indicating that the listed responses are well described by the proposed models. In addition, the fitted models had adequate $R^{2}$, adjusted $R^{2}$, predicted $R^{2}$ and adequate precision values (Table 3), further supporting their use for the approximative prediction of the responses, primarily inside the actual experimental region. The experimental design results were further analyzed, focusing on the assessment of the relative significance of the factors and interactions included in the proposed models by comparing their corresponding coefficients. The smaller the $p$ value, or the higher the magnitude of each coefficient in the coded equation, the higher is the respective factor effect on the response. A negative sign for the factor coefficient indicates an antagonistic effect, whereas a positive coefficient estimate indicates a synergistic effect of the said factor/interaction of factors on the evaluated response. 
Table 3. Final equations in terms of coded factors, estimated model coefficients and statistical analysis (ANOVA) of the generated models for the investigated responses of the developed antiaging creams (A: Emollient concentration; B: Emulsifier concentration)

\begin{tabular}{|c|c|c|c|c|c|c|c|c|c|}
\hline Response & $\begin{array}{l}\text { Coded } \\
\text { equation }\end{array}$ & Source & $\begin{array}{l}\text { Coefficient } \\
\text { estimate }\end{array}$ & $\begin{array}{c}F \\
\text { value }\end{array}$ & $p$ value & $\mathbf{R}^{2}$ & $\begin{array}{c}\text { Adjusted } \\
\mathbf{R}^{2}\end{array}$ & $\begin{array}{l}\text { Predicted } \\
\mathbf{R}^{2}\end{array}$ & $\begin{array}{c}\text { Adeq } \\
\text { Precision }\end{array}$ \\
\hline Apparent & $=$ & Model & & 32.42 & 0.0013 & 0.8438 & 0.8178 & 0.7636 & 10.3155 \\
\hline viscosity & $\begin{array}{l}+14821.85 \\
-808.77^{*} \mathrm{~B}\end{array}$ & $\begin{array}{c}\text { Intercept } \\
\text { B }\end{array}$ & $\begin{array}{c}14821.85 \\
-808.77\end{array}$ & 32.42 & 0.0013 & & & & \\
\hline $\mathrm{G}^{\prime}$ & $\begin{array}{l}= \\
+227.33 \\
+12.78^{*} \mathrm{~A} \\
-3.19^{*} \mathrm{~B} \\
-9.14^{\star} \mathrm{B} 2\end{array}$ & $\begin{array}{c}\text { Model } \\
\text { Intercept } \\
\text { A } \\
\text { B } \\
\text { B }^{2}\end{array}$ & $\begin{array}{c}227.33 \\
12.78 \\
-3.19 \\
-9.14\end{array}$ & $\begin{array}{c}27.23 \\
58.84 \\
3.68 \\
12.04 \\
58.84\end{array}$ & $\begin{array}{l}0.004 \\
0.0016 \\
0.1276 \\
0.0256\end{array}$ & 0.9533 & 0.9183 & 0.7699 & 15.164 \\
\hline G" & $\begin{array}{l}= \\
+25.65 \\
-0.2214^{\star} \mathrm{A} \\
-1.3^{\star} \mathrm{B} \\
-0.3355^{\star} \mathrm{AB}\end{array}$ & $\begin{array}{c}\text { Model } \\
\text { Intercept } \\
\text { A } \\
\text { B } \\
\text { AB }\end{array}$ & $\begin{array}{c}25.65 \\
-0.2214 \\
-1.3 \\
-0.3355\end{array}$ & $\begin{array}{c}116.35 \\
7.71 \\
265.2 \\
10.03\end{array}$ & $\begin{array}{c}0.0002 \\
\\
0.05 \\
<0.0001 \\
0.034\end{array}$ & 0.9887 & 0.9802 & 0.9230 & 28.3884 \\
\hline Yield point & $\begin{array}{l}= \\
+7.55 \\
+1.32^{*} \mathrm{~A} \\
-0.625^{\star} \mathrm{B} \\
-0.515^{*} \mathrm{AB} \\
+0.5767^{*} \mathrm{~A} 2\end{array}$ & $\begin{array}{c}\text { Model } \\
\text { Intercept } \\
\text { A } \\
\text { B } \\
\text { AB } \\
\text { A }^{2}\end{array}$ & $\begin{array}{c}7.55 \\
1.32 \\
-0.625 \\
-0.515 \\
0.5767\end{array}$ & $\begin{array}{c}48.75 \\
\\
185.03 \\
41.27 \\
15.57 \\
15.97\end{array}$ & $\begin{array}{c}0.0046 \\
\\
0.0009 \\
0.0076 \\
0.029 \\
0.0281\end{array}$ & 0.9848 & 0.9646 & 0.9002 & 18.8905 \\
\hline Flow point & $\begin{array}{l}= \\
+75.9 \\
-477^{*} \mathrm{~B}\end{array}$ & $\begin{array}{c}\text { Model } \\
\text { Intercept } \\
\text { B }\end{array}$ & $\begin{array}{c}75.9 \\
-4.77\end{array}$ & $\begin{array}{l}48.32 \\
48.32\end{array}$ & $\begin{array}{l}0.0004 \\
0.0004\end{array}$ & 0.8895 & 0.8711 & 0.8415 & 12.5931 \\
\hline $\begin{array}{l}\text { Loss } \\
\text { factor }\end{array}$ & $\begin{array}{l}= \\
+0.1137 \\
-0.0083^{\star} \mathrm{A} \\
-0.0038^{*} \mathrm{~B} \\
+0.0038^{*} \mathrm{~B} 2\end{array}$ & $\begin{array}{c}\text { Model } \\
\text { Intercept } \\
\text { A } \\
\text { B } \\
\text { B }^{2}\end{array}$ & $\begin{array}{c}0.1137 \\
-0.0083 \\
-0.0038 \\
0.0038\end{array}$ & $\begin{array}{c}522.54 \\
937.5 \\
198.38 \\
79.35 \\
937.5\end{array}$ & $\begin{array}{c}<0.0001 \\
<0.0001 \\
0.0001 \\
0.0009\end{array}$ & 0.9975 & 0.9955 & 0.9901 & 59.6043 \\
\hline $\begin{array}{l}\text { Delta } \\
\text { difference }\end{array}$ & $\begin{array}{l}= \\
+0.9129 \\
-0.5493^{*} \mathrm{~A} \\
-0.1952^{*} \mathrm{~B} \\
+0.4618^{*} \mathrm{AB}\end{array}$ & $\begin{array}{c}\text { Model } \\
\text { Intercept } \\
\text { A } \\
\text { B } \\
\text { AB }\end{array}$ & $\begin{array}{c}0.9129 \\
-0.5493 \\
-0.1952 \\
0.4618\end{array}$ & $\begin{array}{l}10.11 \\
16.58 \\
2.09 \\
6.64\end{array}$ & $\begin{array}{l}0.0245 \\
0.0152 \\
0.2216 \\
0.0616\end{array}$ & 0.8835 & 0.7961 & 0.6648 & 9.3395 \\
\hline
\end{tabular}

a)

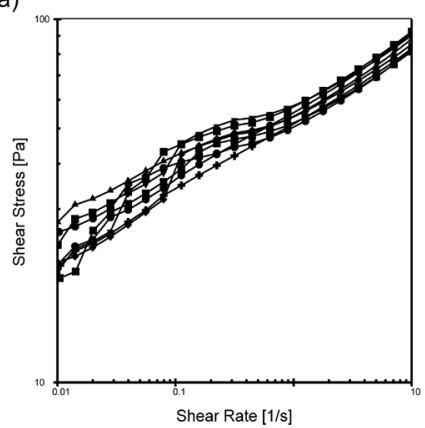

b)

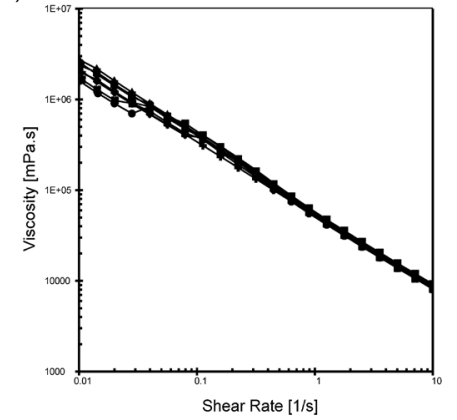

c)

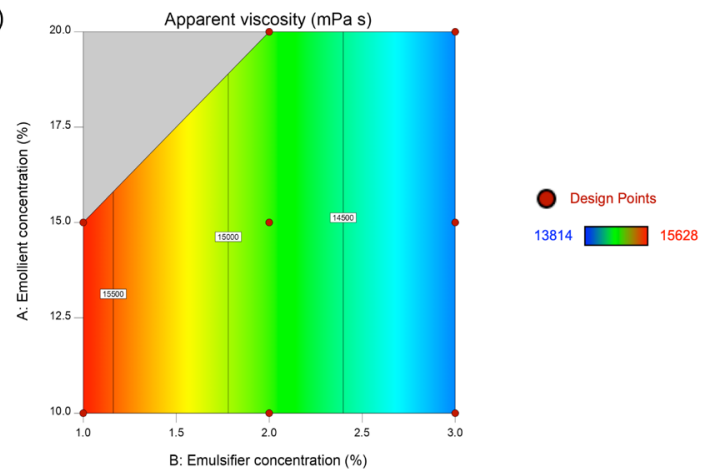

Figure 1. Flow curves (a) and viscosity curves (b) of the developed natural antiaging creams; contour plot for the apparent viscosity (c) as a function of the experimental formulation factors - emollient and emulsifier concentrations.

Rheological characterization

Continuous rotational test

As it can be seen from Figure 1 displaying flow and viscosity curves derived from continuous rotational tests, all prepared model anti-aging creams were characterized by favorable pseudoplastic (shear thinning) flow behavior and exhibited a certain yield point (Table 2). This type of the flow behavior is considered desirable for most 
topically applied formulations, as it facilitates spreading of the product on the skin, as well as squeezing the product out of the tube or picking up the product from the jar. The differences observed in the apparent viscosity values of the model formulations (Table 2) could be attributed to the differences in their composition. However, from Table 3, only the emulsifier concentration (B) was found to be significant and also negative, meaning that the apparent viscosity of the prepared model anti-aging creams decreased when the amount of emulsifier was increased from $1 \%$ to $3 \%$, irrespective of the emollient content in the formulation (Figure 1c).

Oscillatory tests - Amplitude sweeps

As a part of further rheological characterization, amplitude sweeps were performed to obtain the information about the viscoelastic character of the prepared model anti-aging creams, through establishing the relationship between the storage modulus G' (as a measure of the deformation energy stored in the system during shear process; reflects the solid character (the elastic part) of the sample) and loss modulus G" (as a measure of the deformation energy lost during shearing through 'viscous heating' phenomenon; reflects the liquid character (the viscous part) of the sample) in the LVE region [12]. The resulted amplitude sweep graphs, presented in Figures $2 a$ and $2 b$, suggested that all model anti-aging creams exhibited dominating elastic behavior over viscous one ( $G^{\prime}>G^{\prime \prime}$ ) in the LVE range, indicating the character of viscoelastic solid at $\omega=10 \mathrm{rad} / \mathrm{s}$, and certain physical stability at the relative state at rest [15]. The experimental design results (Table 3) further indicated that both viscoelastic moduli (G' and G") were significantly influenced by the formulation composition, and the effects are illustrated graphically via 3D surface plots in Figures $2 \mathrm{c}$ and $2 \mathrm{~d}$.
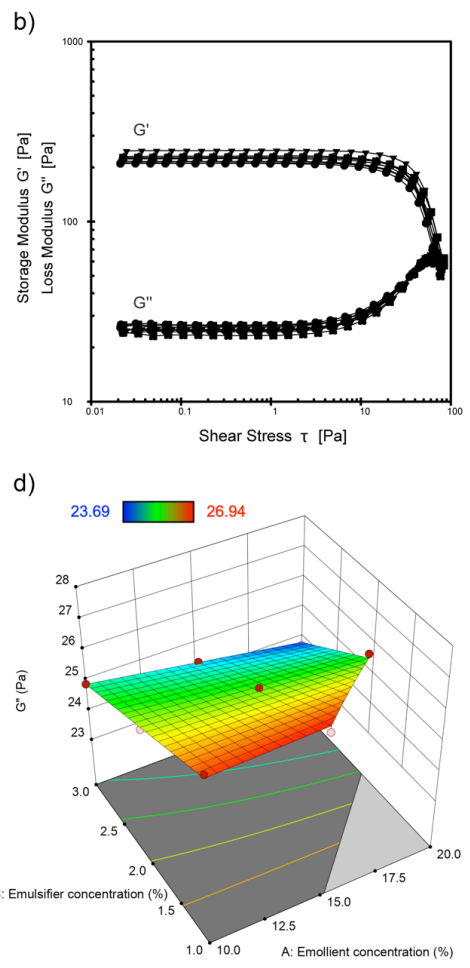

Figure 2. Amplitude sweeps of model natural anti-aging creams - storage and loss moduli vs. shear strain (a) and storage and loss moduli vs. shear stress (b); 3D surface plots for the storage modulus G' (c) and loss modulus G" (d) as a func-

As it can be seen from Table 3 and Figure 2c, the concentration of emollients $(A)$ created a linear increasing effect on the $\mathrm{G}^{\prime}$, imposing the higher storage modulus of anti-aging creams formulated with higher emollient content ( $G^{\prime} 20 \%$ emollient > G' $15 \%$ emollient > G' $10 \%$ emollient). The surface also exhibits significant nonlinearity in the emulsifier concentration - factor B curves up and then down creating the increased $G$ ' response at the center. In other words, increasing the emulsifier content from $1 \%$ to $2 \%$ resulted in higher G' value, whereas further increasing of the emulsifier concentration to $3 \%$ yielded the anti-aging creams with the lower $G^{\prime}$ modulus. This is caused by the negative coefficient on the squared term $\left(B^{2}\right)$ in the G' model (-9.14, Table 3). Considering the G" parameter, Table 3 reveals that both studied factors, as well as their interaction, exerted significant and inverted effects, with the emulsifier concentration having the greatest influence. The higher emulsifier concentration produced anti-aging creams with lower loss modulus, whereby the variation in the emulsifier concentration (the increase from $1 \%$ to $2 \%$ and further to $3 \%$ ) was the most effective in changing (reducing) the G" of anti-aging creams 
prepared with $20 \%$ of emollients (Figure $2 d$ ). Moreover, when $3 \%$ of emulsifier was used, a tendency of apparent G" decrease was shown when the emollient concentration in the model cream was increased from $10 \%$ (to $15 \%$ ) to $20 \%$, while negligible reduction was observed in formulations with $1 \%$ and $2 \%$ emulsifier (Figure $2 d$ ). Comparing the ratios of viscous and elastic modulus (G"/G' = tanס, loss factor) of formulated creams, quite similar values were reported (Table 2); the fairly small differences could be assigned to the emollient $(A)$ and, to a lesser extent, to the emulsifier $(B)$ concentration (Table 3, Figure 3c). The lower loss factor values correlated with the higher emollient and emulsifier concentrations, whereby no significant differences were observed in creams stabilized with $2 \%$ and $3 \%$ of emulsifier.

One more parameter extracted from the amplitude sweeps was the yield point (Table 2, Figure 3a), determined as the shear stress value at the limit of the reversible deformations' (LVE) range (that is the shear stress value at which $G^{\prime}$ deviated for more than 3\% compared to the LVE range). Considering that it is still in the LVE region, the yield point obtained from the amplitude sweeps is preferred over the yield point calculated from the continuous rotational tests and, hence, it is a better indicator of the emulsion system structure and stability $[12,15]$. Table 3 reveals that the yield point of the developed antiaging creams was significantly influenced by both individually tested formulation variables, as well as by their combined effect with the following order: emollient concentration $(A)>$ emulsifier concentration $(B)>$ interaction between the emollient and emulsifier concentration $(A B)$. The emollient content revealed a positive influence on the yield point of the model creams: the lower yield point was found to correlate with the lower emollient concentration $(10 \%)$, while a higher emollient concentration (15\% and $20 \%$ ) produced anti-aging creams with a higher yield point. A negative sign for the coefficient of the emulsifier concentration represented an antagonistic effect on the yield point, meaning that the yield point of anti-aging creams stabilized with a higher amount of the emulsifier $(3 \%)$ was smaller, compared to those prepared with the lower emulsifier concentration ( $2 \%$ and $1 \%)$. When analyzing the factor interaction (Figure 3a), it is apparent that only negligible difference in the yield point of anti-aging creams containing $10 \%$ of emollients was observed when the amount of emulsifier was changed from $1 \%$ to $3 \%$. In case of anti-aging creams prepared with $15 \%$ and, particularly, with $20 \%$ of emollients, the trend of the pronounced decrease in the yield point could be noticed with increasing the emulsifier concentration. Furthermore, whichever concentration of emulsifier was chosen to prepare and stabilize anti-aging creams, increasing the emollient content from $10 \%$ to $15 \%$, and further to $20 \%$ resulted in the favored increase of the yield point, with the most pronounced increase observed in the formulation stabilized with $2 \%$ of the emulsifier (Figure $3 a$ ).
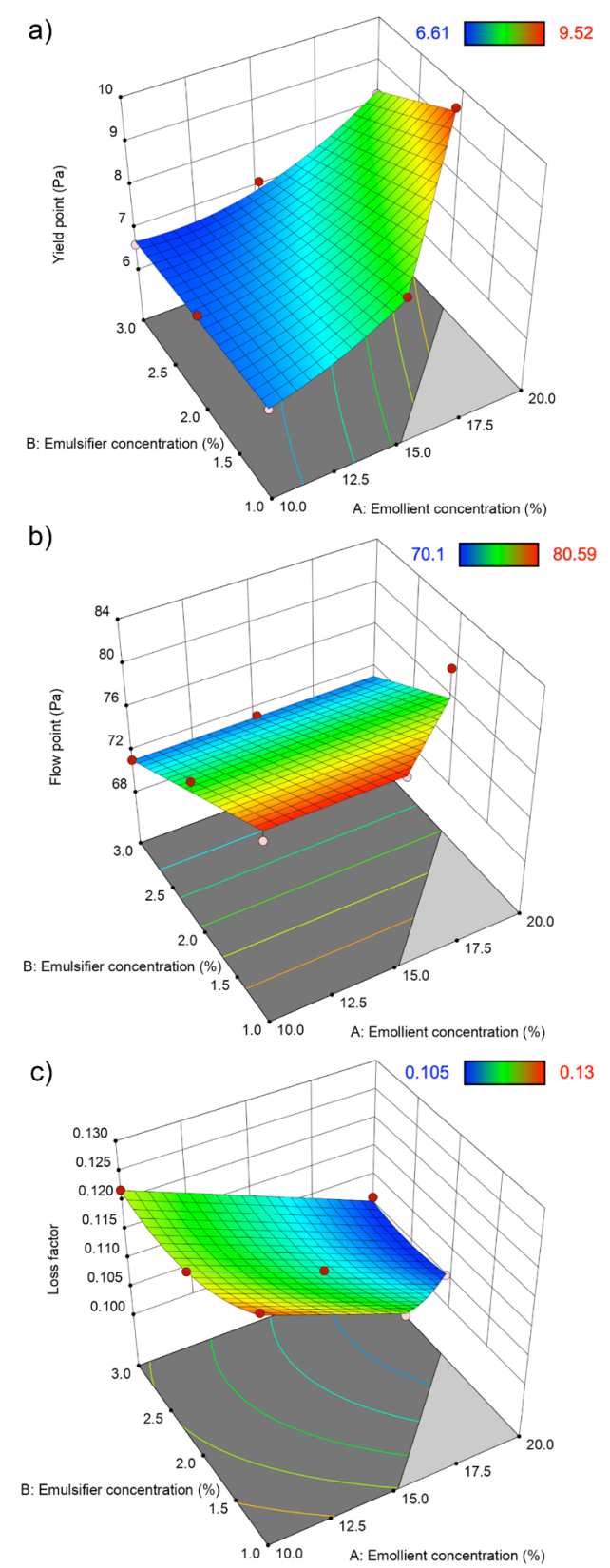

Figure 3. Response surface plots for the yield point (a), flow point (b) and loss factor (c) of model natural antiaging creams as a function of the experimental formulation factors.

Besides the yield point, the flow point - determined as the shear stress value where the structure breaks (at the crossover point $\left.G^{\prime}=G^{\prime \prime}\right)$, that is, the shear stress value beyond which the analyzed system starts to flow $[12,15]$ - is another important rheological characteristic acquired from the amplitude test. Since it is located in the range where irreversible structural changes or a complete structure breakdown started to happen, this parameter is scientifically less reliable, but preferable in practice (mixing, pumping, packaging, filling, storage) $[12,15]$. Table 2 shows that the flow point values of all developed model anti-aging creams were in the range of 70-80 $\mathrm{Pa}$, which were both indistinguishable and sat- 
isfying in practical terms. During the model fitting procedure, it was found that the flow point of the investigated creams was only significantly influenced by the emulsifier concentration (B) (Table 3), in the manner that the flow point decreased with increasing the amount of the emulsifier from $1 \%$ to $3 \%$, that is, the highest flow point was observed in formulations stabilized with $1 \%$ of the emulsifier, regardless the emollient concentration used (Figure 3b).

\section{Oscillatory tests - Frequency sweeps}

In order to characterize the emulsion internal structure at rest and long-term storage stability of the developed natural anti-aging creams, frequency sweeps, describing the time-dependent behavior in the LVE range and thus both, the short- and long-term physical stability of emulsions $[12,15]$ were performed. The resulting frequency sweep graphs, presented in Figure 4, demonstrated that G' curves of all model anti-aging creams dominated their corresponding G" curves over entire frequency range (0.01-100 rad/s), indicating that the 3D network physical structure has been built up $[12,15]$. Furthermore, by analyzing the acquired G' curves (Figure 4), as well as $G^{\prime}$ values obtained at the lowest angular frequency $(\omega=$ $0.01 \mathrm{rad} / \mathrm{s}$ ), all investigated model formulations could be characterized by a relatively constant structural change in the whole frequency range used, ending up with $\mathrm{G}^{\prime}$ values > $10 \mathrm{~Pa}$ at $\omega=0.01 \mathrm{rad} / \mathrm{s}$ (Figure 4), thus implying a fairly good structural strength (rigidity) at rest [12]. These findings further suggested good long-term stability profiles (shelf-life stability) of the developed anti-aging creams but could not provide data for differentiating between similar frequency sweep profiles of the creams studied. In that regard, routinely conducted temperature cycling stress test (freeze-thaw test and/or its rapid rheological simulation - DMTA test) could help to obtain more conclusive data on the physical stability and additionally distinguish between several similar formulations for the further development or quality status determination.

Physical stability study - DMTA test

To gain the more comprehensive insight into physical stability of the developed model anti-aging creams during the temperature variations (transport, storage, use) and, therefore, complement the findings of isothermal frequency sweeps, the DMTA test, consisting of rapidly simulating freeze-thaw cycles was employed in this study. Compared to at least 12 days typically required for conventional freeze-thaw test in the stability chamber $\left(45^{\circ} \mathrm{C} / 24 \mathrm{~h} ;-5{ }^{\circ} \mathrm{C} / 24 \mathrm{~h}\right.$, minimum 6 cycles), properly programmed DMTA test allowed us to evaluate the thermal stability of the developed anti-aging creams in a significantly shorter time (about $2 \mathrm{~h}$ per formulation). Looking closely at the DMTA graph, the trend of the sample structural change during the test can be easily observed through a series of $G^{\prime}$ peaks corresponding to the temperature plateau at $20{ }^{\circ} \mathrm{C}$, where each peak indicates the change of $\mathrm{G}^{\prime}$ prior to temperature oscillation (initial value) and after each conducted stress test cycle $[10,11]$

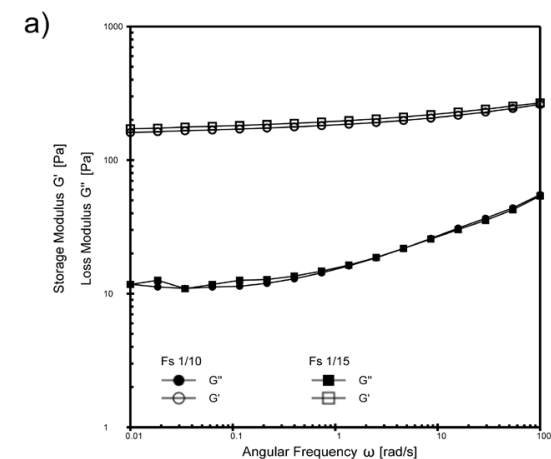

b)

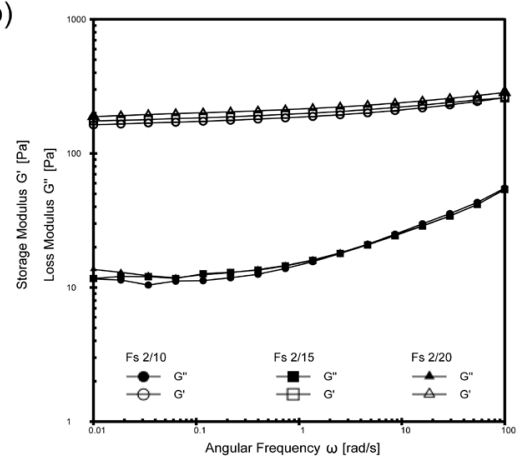

c)

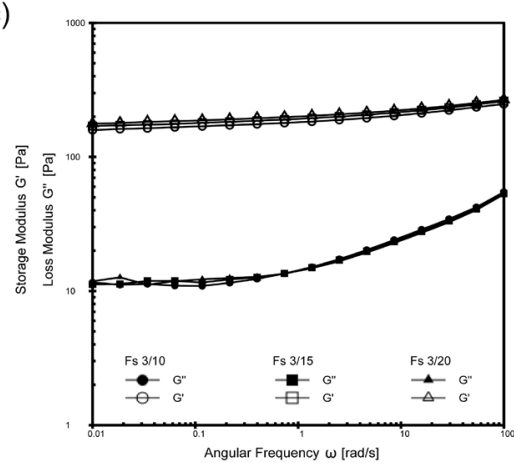

Figure 4. Frequency sweeps of model natural anti-aging creams - Fs $1 / 10$ and Fs $1 / 15$ (a), Fs $2 / 10$, Fs $2 / 15$ and Fs 2/20 (b), and Fs 3/10, Fs 3/15 and Fs 3/20 (c).

The DMTA diagrams showing the structural change (Delta) of the selected model anti-aging cream (Fs 2/20) are presented in Figures $5 \mathrm{a}$ and $5 \mathrm{~b}$. Figure $5 \mathrm{~b}$ represents an enlarged inset of Figure 5 a for narrower storage modulus range ( $\mathrm{G}^{\prime} 231-241 \mathrm{~Pa}$ ). As it can be seen (Figure $5 \mathrm{~b}$ ), the structural change Delta of the selected Fs 2/20 cream first negligibly increased, after the first two test cycles, and then showed a negligible exponential decrease, reaching the value of $0.996 \pm 0.006$ (Table 2), after the last cycle of the applied temperature stress test. The similar trend of Delta change could be also observed for other investigated model creams, except formulations Fs $1 / 10$ and Fs 2/15, which showed a linear decrease of Delta values throughout the testing. However, here it is important to emphasize that the recorded changes of Delta values for all tested model creams were rather small and almost constant, indicating their excellent physical stability; the structural change at the end of the DMTA test deviated from the initial value by only 0.4-2.1\% (Delta difference, Table 2), with the lowest extent of Delta change obtained for formulation Fs 2/20. 

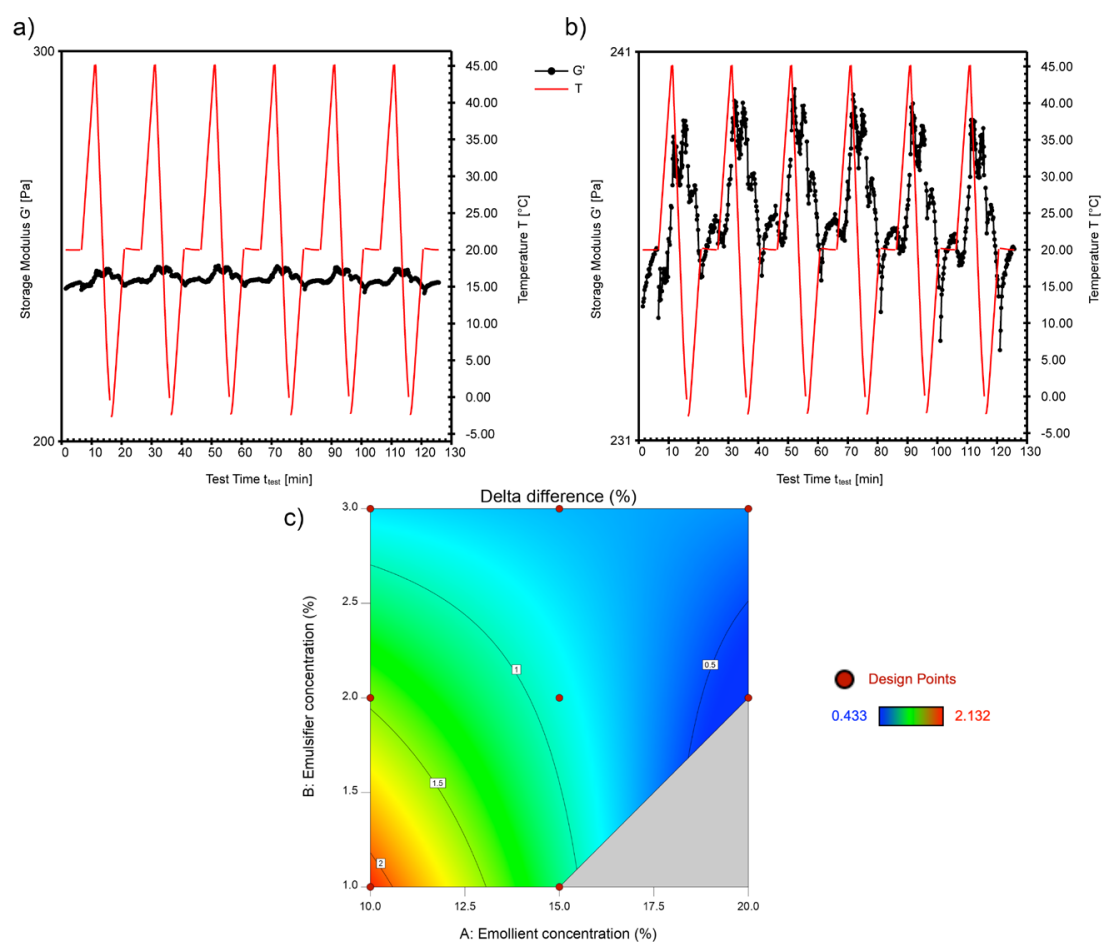

Figure 5. Change of storage modulus $\mathrm{G}^{\prime}$ in the DMTA test for selected model formulation Fs 2/20 (a, b); contour plot for the Delta difference (c) of model natural anti-aging creams as a function of the experimental formulation factors.

Based on ANOVA statistics (Table 3), the emollient concentration was found to have a significant negative effect on the Delta difference as a measure of the structural change of the investigated anti-aging creams, while the interaction of emollient and emulsifier showed only marginal influence $(0.05<0.0616 p$-value for $A B<0.1)$. The effects of the concentration of emollients $(A)$ and emulsifier $(B)$, and their interaction $(A B)$ on the Delta difference value of the developed model anti-aging creams are visualized in Figure 5c. The Delta difference value, i.e., the percent of a structural change was lower when the higher emollient concentration was used in the formulation. Moreover, the increase in the emollient concentration from $10 \%$ to $15 \%$, and further to $20 \%$, was the most effective in decreasing the Delta difference values of model creams stabilized with $1 \%$ and $2 \%$ of the emulsifier, respectively, whereas the Delta differences value of creams prepared with $3 \%$ of the emulsifier was almost unchanged. In addition, when the concentration of the emulsifier used was changed from $1 \%$ to $2 \%$, a tendency of Delta difference decrease was shown in creams prepared with $10 \%$ of emollients, contrary to the creams containing $15 \%$ of emollients where Delta difference values tended to increase. However, a further increase in the emulsifier concentration to $3 \%$ caused a decrease in Delta difference values for both described cases, whereas no significant differences were observed for creams prepared with $20 \%$ of emollients (Figure 5 c).
Natural anti-aging cream formulation optimization

After analyzing the effects of investigated formulation variables on the rheological properties of the developed creams, their simultaneous numerical and graphical optimization (as a part of RSM D-optimal design study) was conducted in order to establish the factor levels' combination yielding the natural anti-aging creams with desired/ optimal rheological behavior, and, therefore, desired/adequate quality and stability profiles. In the numerical optimization procedure, the selected desired goals for each tested factor (emollient: 10-20\%; emulsifier: 1-3\%) and response (Delta difference value: set to be minimized; yield point: set to be maximized; G', flow point, apparent viscosity: set to be in experimental range) were combined into an overall desirability function and the global desirability value ranging from 0 (least desirable) to 1 (most desirable) $[8,14]$ was calculated.

The resulting desirability contour plot and overlay plot of optimized cream formulations are presented in Figures $6 a$ and $6 b$, respectively. The unshaded "optimized" area in the overlay plot represents factor combinations yielding the model creams with desirable/acceptable rheological properties according to the defined optimality criteria, whereas the regions not meeting these criteria are shaded. By inspection of graphs (and verified by numerical optimization), the minimum Delta difference (the lowest percent of structural change) and the peak yield point and G' values, along with the satisfied apparent viscosity and flow point values could be found at the emollient concentration of $20 \%$ and the emulsi- 
fier concentration of $2 \%$, and this factor combination was suggested as preferred (desirability value 0.988 , close to optimum) to achieve targeted rheological behavior of the resulting natural anti-aging cream (Figure 6).
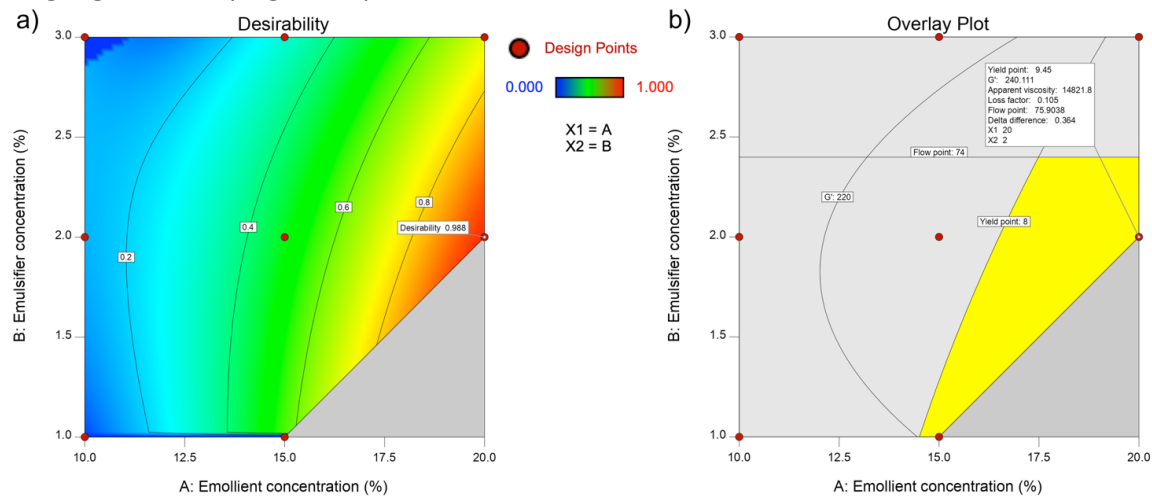

Figure 6. Contour plot (a) and overlay plot (b) for an overall desirability of model natural anti-aging creams.

\section{Conclusion}

In this work, eight natural cream formulations, differing in the concentration of emollients and emulsifier and containing $A$. oleracea extract as a model anti-aging active, were prepared with cold process, rheologically characterized by continuous rotational and oscillatory tests, and subjected to stability evaluation by employing DMTA test. To determine and evaluate how the change in the formulation composition influenced the rheological properties and, therefore, the quality and stability of the developed anti-aging creams, a systematic design of experiments approach was successfully applied. Combining all the results, the following main conclusions could be drawn:

(1) All prepared model creams displayed desirable shear-thinning flow behavior with a certain yield point and exhibited the character of viscoelastic solids (elastic behavior dominated viscous one) in the LVE region of amplitude sweeps, as well as in frequency sweeps;

(2) Not only investigated factors alone (emollient concentration, emulsifier concentration), but also their interaction had a significant effect on the rheological characteristics as critical quality attributes of the developed anti-aging creams, as confirmed by RSM D-optimal design study;

(3) The rather small extent of Delta change at the end of the DMTA test, together with other rheological parameters acquired from the oscillatory analysis (yield point, flow point, storage modulus, loss factor), indicated a satisfying overall stability profile of the developed antiaging creams.

(4) By employing DMTA method as a high-performance rheological simulation of accelerated freeze-thaw stability testing of emulsion systems, subtle differences in rheological behavior and, hence, stability profiles of formulated creams could be addressed in a matter of few hours.
(5) From the optimization study, among the tested creams, the model formulation prepared with $20 \%$ of emollients and $2 \%$ of emulsifier could be preferable in terms of rheological properties (the highest yield point and G', the lowest structural change) and, thus, stability and quality, and it could be considered as promising natural anti-aging cream candidate. Further investigations are necessary to determine whether the observed findings may have practical relevance and the significant influence on the efficacy and in vivo skin performances of the final product.

\section{Acknowledgments}

This work was supported by the Ministry of Education, Science and Technological Development, the Republic of Serbia, within the framework of the Financing program for scientific research, ev. no. 451-03-68/202014/200133. The authors would like to thank Mrs. Marina Cekić (DCP Hemigal d.o.o., Leskovac, Serbia) and to Mr. Marko Racković (MC Labor d.o.o., Belgrade, Serbia) for technical support.

\section{Abbreviations and Symbols}

Adeq Precision Adequate precision, signal-to-noise ratio

Adjusted $\mathrm{R}^{2}$ Adjusted multiple correlation coefficient ANOVA Analysis of variance

$\triangle \quad$ Structural change Delta

$\Delta_{\text {difference }} \quad$ Delta difference

DMTA Dynamic-mechanical thermoanalysis

DoE Design of experiments

G' Storage modulus

G" Loss modulus

INCI International Nomenclature of Cosmetic Ingredients

LVE region Linear viscoelastic region 


$\begin{array}{ll}\text { Predicted } & R^{2} \text { Predicted multiple correlation coefficient } \\ \mathrm{R}^{2} & \text { Multiple correlation coefficient } \\ \mathrm{RSM} & \text { Response surface method } \\ \tan \delta & \text { Loss factor (G"/G') } \\ \omega & \text { Radial frequency } \\ \mathrm{V}_{\mathrm{L}} & \text { Limiting deformation, deformation limit }\end{array}$

\section{References}

[1] Y. H. Chang, Consumer and formulator of natural cosmetics: understanding and integrating each other's needs, in Formulating, packaging, and marketing of natural cosmetic products, N. Dayan, L. Kromidas Eds., John Wiley \& Sons, Inc., Hoboken, New Jersey, 2011, p. 15.

[2] N. Wilson, Market evolution of topical anti-aging treatments, in Skin aging handbook: an integrated approach to biochemistry and product development, N. Dayan Ed., William Andrew Inc., Norwich, New York, 2008, p. 15.

[3] L. F. de Jesus, M. Fernandez, A. Pavanelli, Green emollients and their application in $\mathrm{O} / \mathrm{W}$ emulsions for personal care, SOFW-Journal, 139(6) (2013) 26 - 29.

[4] D. Cernasov D, The design and development of antiaging formulations, in Skin aging handbook: an integrated approach to biochemistry and product development, N. Dayan Ed., William Andrew Inc., Norwich, New York, 2008, p. 291.

[5] G. M. D. Costa, G. D. A. D. Alves, P. M. B. G. Maia Campos, Application of design of experiments in the development of cosmetic formulation based on natural ingredients, International Journal of Phytocosmetics and Natural Ingredients, 6(1) (2019) 4.

[6] D. D. Peres, M. B. Ariede, T. M. Candido, T. S. de Almeida, F. R. Lourenço, V.O. Consiglieri, T. M. Kaneko, M. V. Velasco, A. R. Baby, Quality by design (QbD), Process Analytical Technology (PAT), and design of experiment applied to the development of multifunctional sunscreens. Drug Development and Industrial Pharmacy, 43(2) (2017) $246-256$.

[7] A. Kovács, I. Erős, I. Csóka, Optimization and development of stable w/o/w cosmetic multiple emulsions by means of the Quality by Design approach, International Journal of Cosmetic Science, 38(2) (2016) 128 - 138.

[8] R. H. Myers, D. C. Montgomery, C. M. Anderson-Cook, Response surface methodology: process and product optimization using designed experiments, 3rd edition, Wiley, New York, 2009.

[9] S. N. Politis, P. Colombo, G. Colombo, D. M. Rekkas, Design of experiments (DoE) in pharmaceutical development, Drug Development and Industrial Pharmacy, 43(6) (2017) 889 - 901.

[10] N. Cekic, S. Savic, S. Savic, Dynamic-mechanical thermoanalysis test as a high-performance alternative for accelerated freeze-thaw stability testing: a case study of $\mathrm{O} / \mathrm{W}$ emulsions, Drug Development and Industrial Pharmacy, 46(3) (2020) 505 - 520.

[11] N. Cekic, S. Savic, S. Savic, Dynamic-mechanical thermoanalysis test: a rapid alternative for accelerated freeze-thaw stability evaluation of W/O emulsions, Drug Development and Industrial Pharmacy, 45(12) (2019) 1896 - 1906.

[12] T. G. Mezger, The Rheology Handbook: for users of rotational and oscillatory rheometers, 4th edition, Vincentz
Network GmbH \& Co. KG, Hanover, 2014

[13] M, Bernzen, Determination of the mechanical and thermal stability of skin cream with oscillation and freeze-thaw cycle tests, 2018, Available from: http://s21.co.kr/m/view. jsp?ncd=3026 (last access 10.10.2020).

[14] M. J Anderson, P. J. Whitcomb, RSM simplified: optimizing processes using response surface methods for design of experiments, 2nd edition, CRC Press: Taylor \& Francis Group, Boca Raton, 2017.

[15] T. G. Mezger, Applied rheology: with Joe Flow on rheology road, 4th edition, Anton Paar, Graz, 2017. 


\section{PRIMENA D-OPTIMALNOG DIZAJNA EKSPERIMENATA I SVEOBUHVATNE REOLOŠKE ANALIZE U RAZVOJU PRIRODNIH ANTI-AGING KREMOVA}

Sanela M. Savić ${ }^{1}$, Nebojša D. Cekić ${ }^{1}, 2$, Saša R. Savić

${ }^{1}$ DCP Hemigal, Leskovac, Srbija

${ }^{2}$ Tehnološki fakultet, Univerzitet u Nišu, Leskovac, Srbija

Cilj ovog rada bio je razvoj i procena potpuno prirodnih anti-aging kremova uz primenu eksperimentalnog dizajna. Model formulacije koje su se razlikovale samo po sadržaju emolijenasa $(10 \% / 15 \% / 20 \%)$ i emulgatora $(1 \% / 2 \% / 3 \%)$, i koje su sadržale ekstrakt biljke Acmella oleracea kao model aktivnu supstancu, izrađene su hladnim postupkom i okarakterisane u pogledu reološkog ponašanja (kontinualni rotacioni i oscilatorni testovi) i fizičke stabilnosti (dinamičko-mehanički termoanalitički-DMTA test). $U$ cilju procene uticaja variranih formulacionih parametara i njihove interakcije na kritične reološke karakteristike razvijenih kremova, primenjen je D-optimalni dizajn u okviru metodologije površine odgovora. Podaci dobijeni reološkom karakterizacijom pokazali su poželjno pseudoplastično tečenje (shear-thinning) sa prinosnom vrednošću, kao i dominantno elastično ponašanje (elastični modul G' > viskozni modul G") u amplitudnim i frekventnim testovima, što je zajedno sa izrazito malom i konstantnom strukturnom promenom zabeleženom u DMTA testu ukazivalo na zadovoljavajuću sveukupnu fizičku stabilnost formulisanih kremova. Rezultati Doptimalnog dizajna pokazali su značajne pojedinačne efekte, kao i zajednički efekat ispitivanih formulacionih faktora (koncentracija emolijenasa, koncentracija emulgatora) na kritične atribute kvaliteta (prividni viskozitet, napon popuštanja, tačka tečenja, G', G", strukturna promena) razvijenih anti-aging kremova. Na osnovu rezultata optimizacije, model formulacija koja je sadržala $20 \%$ smeše emolijenasa i $2 \%$ emulgatora odabrana je kao optimalna u pogledu zahtevanih reoloških svojstava i, time, poželjne stabilnosti i kvaliteta, i može se smatrati obećavajućim kandidatom za dalja ispitivanja u smislu efikasnosti i in vivo performansi na koži
(ORIGINALNI NAUČNI RAD) UDK 665.58:66.06

DOI: 10.5937/savteh2002029S perimentalni dizajn, reološki parametri, kontinualni rotacioni test, oscilatorni test, DMTA metod 